\title{
Chapter 3 \\ Legal Paradigm Shifts and Their Impacts on the Socio-Spatial Exclusion of Asylum Seekers in Denmark
}

\author{
René Kreichauf
}

\subsection{Introduction}

The case of Denmark illustrates a changing story of a country that once was the first nation to ratify the 1951 Refugee Convention to a country where its Prime Minister called for an end to the convention in 2016 (Kingsley 2016). Especially during and in the aftermath of the so-called "European Refugee Crisis", Denmark's "harsh new immigration law" (Boserup 2016), its "inhumane family reunification" regulations (Dearden 2016) and "deterrence tactics" (Simpson 2016) have caused international attention. This shift did not take place over night. Since the early 1990s, Danish asylum legislations have been revised and toughened several times, often because of increasing arrivals as well as rising neo-nationalism and anti-immigrant sentiments.

Denmark's relation with the EU in the fields of immigration and asylum reflects this development. It holds opt outs on EU Justice and Home Affairs and stands outside of the Common European Asylum System (CEAS). Its asylum and immigration legislations thus differ from the rest of the EU, which makes Denmark a special and, as I will discuss in this chapter, an extreme case regarding the arrival and integration of asylum seekers and refugees.

There is a broad scholarship on the development of immigration and asylum legislations in Denmark and the transformation of its asylum system from humanitarianism to nationalism (see i.e. Jaffe-Walter 2016; Hedetoft 2006). However, scholars have paid little attention to the impacts of asylum and immigration laws on

\footnotetext{
R. Kreichauf $(\triangle)$

Freie Universität Berlin, Berlin, Germany

Vrije Universiteit Brussel, Brussels, Belgium

e-mail: rene.kreichauf@fu-berlin.de 
reception practices, the development of Denmark's centre system as well as to the living conditions of forced migrants.

In this chapter, I analyse the development of the Danish asylum legislations and their influence on the country's reception practices and on the well-being of forced migrants. I argue that their reception and initial settlement in Denmark is, first, the domain of the state, whereas municipalities have little power to decide. Second, I contend that accommodation has increasingly been transformed into large, camplike structures with lowered living standards and a closed character because of the tightening of asylum laws. I finally argue that Denmark's centre system reflects the materialisation and socio-spatial consequences of changes in legislations. I reveal how the state's restrictive laws are put into practice and are translated into space reinforcing Denmark's policy on the strategic isolation of forced migrants.

To understand the development of the Danish asylum legislations and their influence on the country's reception and settlement practices as well as on the well-being of forced migrants, I contextualise the Danish case in the literature and present my theoretical and methodological approaches (Sect. 3.2). I continue with explaining Denmark's traditions in handling asylum seekers and refugees since WWII with a focus on current developments (Sect. 3.3). This is followed by a precise outline of refugee laws, Denmark's special position in the European asylum regime as well as explanations of current political and legal practices (Sect. 3.4). Then I present and discuss empirical findings on the socio-spatial exclusion of forced migrants through accommodation and placing in remote camps in Denmark's Hovedstaden Region (Sect. 3.5). Within this part, I elucidate the structures, objectives and spatial configurations of the Danish camp system. In my conclusion (Sect. 3.6), I discuss the translation of policies into spatial dimensions and highlight avenues for further research.

\subsection{Studying Refugee Reception and Accommodation Practices in Denmark}

In most European countries, refugees are usually allocated to states and municipalities according to allocation quotas, which are often calculated based on economic activity and the number of inhabitants in a region. The political motivation often lies in spatially constructing and arresting refugees "through bureaucratic labelling and assignment to heterotopias" - processes, which "freeze the forced migrant in a place" (Witteborn 2011: 1142). Dispersal, first reception and resettlement are policy areas and processes that are linked with each other in the trajectories of arriving forced migrants. They make up a large part of research on refugees in the global north. Even though, dispersal and resettlement policies are not per se local policies, they result in the arrival of refugees in and close to cities and municipalities, which depending on national asylum laws - are responsible for accommodation and support. Dispersal and reception practices are governmental processes, which localize 
and transfer issues of maintenance, welfare support and the management of forced migrants to the level of cities and municipalities (Darling 2016). Because of dispersal policies some regions and municipalities become destinations for migrants in the first place. This "forced arrival" (Kreichauf 2018) confronts some cities to react and develop reception approaches and accommodation schemes, which otherwise would have barely experienced immigration.

In the European context, studies on dispersal and reception focus on the role of municipalities and communities in organizing and accommodating arrivals, institutional challenges, civil society engagements, and shifts in local policies (Aumüller et al. 2015; Ikizoglu Erensu and Kasli 2016; Lidén and Nyhlén 2016; Steen 2016). Breckner (2015: 1) finds a "new sensibility" regarding the "localization of provisionary housing, institutional practices and in the acceptance of civil engagement" studying the local living conditions of forced migrants in Hamburg. Studies on reception experiences often investigate the first phase of arrival and the reactions of administrative bodies dealing with the management of forced migrants. They include health care, material and welfare provisions as well as the implementation of the EU reception directive (see for example Rosenberger and König 2011). Particularly UK geographers such as Phillimore and Goodson (2006), Spicer (2008), O'Mahony and Sweeny (2010), but also Kreichauf (2019) illustrate the local distribution of refugees within a city, mostly in disadvantaged neighbourhoods or sociospatially excluded in refugee camps outside of settlements.

Referring to the Danish case, Wren (2003) shows that, in contradiction to the state's objective to prevent the concentration of migrants, dispersal policies have resulted in processes of socio-spatial ethnic segregation in deprived areas reinforcing exclusion and anti-refugee hostility. Larsen's (2011) ethnographic field research expounds that dispersal policies and the placing of migrants hinder the establishment of relationships to co-ethnics and relatives and ultimately the incorporation in the Danish welfare society.

A strong body of research studies the reception and accommodation of refugees in European states, which is usually managed by the development of mass accommodation, asylum centres and refugee camps (EMN 2014). Many theoretical concepts have been developed based on camps in African countries and the Middle East, most prominently by Ramadan (2013), Sanyal (2014), and Malkki (1995). In the camp literature, the camp is conceptualised as a space of exception and biopolitics (Diken and Laustsen 2005; Edkins 2000; Hyndman 2000) or as sites in which new identities, acts of agency, political life, and resistance are formed and practiced (Ramadan 2013; Salih 2017; Redclift 2013). In the North, studies analyse the 'asylum centre' and the living conditions of forced migrants in those accommodations. The research stress the genesis of mass accommodation systems in EU member states and the exclusion of asylum seekers through these large accommodations (see for example Darling 2009; Dwyer and Brown 2008; Hirschler 2013; Kublitz 2016; Szczepanikova 2013; Witteborn 2011). Most of the studies describe them as places of states of exceptions and as border areas, where the state has unlimited power to decide on the inclusion or exclusion of immigrants. 
Regarding the Danish case, Syppli Kohl (2016) explains the development and shifts of the centre system, its main characteristics and trends of socio-spatial exclusion and exploitation due to labour programs in the camps. Kublitz (2016) illustrates the living conditions of Palestinian refugees in Danish centres. She argues that accommodations are "characterized by minor mundane catastrophes, infinite unbecomings that slowly erode the lives" (Kublitz 2016: 246). Research on the arrival accommodation in Denmark lacks analyses on the specific socio-political and socio-spatial functions of centres as well as on their socio-spatial settings. For that reason, this chapter links the tensioning of laws with the emergence and changes of the Danish centre system. I expound how restrictive laws not only impact the sociospatial configurations and characteristics of refugee shelters, but how they reinforce and legitimize Denmark's harsh dealings.

I conceptualise the camp as a site of bordering (Darling 2016) that denies refugees' movement and mobility and that is a part of a camp-border urban development (Diken and Laustsen 2005). In another work (Kreichauf 2018), I have established the concept of "campization" to describe the development of camp-like accommodations in Europe and to capture that changes in asylum laws have stimulated a transformation of refugee accommodations. Campization is a process that explains two tendencies of accommodating refugees in the context of increasing numbers arriving in EU member states and the tightening of laws on asylum, and explicitly on reception:

First, the legal stabilization of permanent, enlarged, remotely located, and spatially isolated camps with lowered living standards, increased capacities, and a closed character; and second, the changing notions and forms of containment, exclusion, and temporality of these infrastructures. These tendencies are reflected architectonically, functionally, and sociospatially. (Kreichauf 2018, 4).

I apply this concept in this chapter to explain the emergence and deepening of camp-like characteristics of Danish refugee accommodation and to reveal reception and accommodation practices as Denmark's central instruments to strategically isolate and deter forced migrants.

The following empirical findings are based on qualitative research conducted from 2013 to 2016. It contains multi-level policy analyses of major law and policy changes as well as of the development of political and societal discourses on (forced) migration in Denmark. I also included socio-spatial analyses of following asylum centres in or close to Hovedstaden: Centre Sandholm, Centre Kongelunden and Centre Avnstrup. Thirteen semi-structured interviews on the accommodation, living conditions of forced migrants and the impact of law changes on local receptions were conducted on following levels between 2013 and 2016: 1) decision makers and administrative bodies (2),2) civil society actors, local refugee organisations and initiatives (6) and 3) asylum seekers and refugees (5). The aim of the three-leveldivision was to develop a broad context of findings on perception of social structures, power relations and effects in and of accommodations from various actors. Many more informal interviews with forced migrants have been carried out. Those 
were used as observations written down in a research diary as part of the "Go along" method (Kusenbach 2003).

Within this chapter, I cite interviews I conducted with the Danish Immigration Service and the Danish Red Cross as the major administrative and operative bodies regarding accommodation, Asylret, Danish Refugee Council, Refugees Welcome and the Trampoline House as the leading refugee organizations as well as interviews with forced migrants in the Hovedstaden Region.

\subsection{Post-WWII and Recent Refugee Reception Experiences in Denmark}

Denmark was one of the first countries to become a party of the 1951 Refugee Convention and the first state to ratify the treaty in 1952 entering force in 1954. It acceded to the 1967 Protocol in 1968 and it further ratified the 1954 Convention relating to the status of Stateless Persons in 1956 and the 1961 Convention on the Reduction of Statelessness in 1977. Denmark's international performance as an active supporter of the development of an international protection regime characterised its welcoming attitude towards refugees in the first decades after WWII (Jønson and Peterson 2012).

In 1983, the Aliens Act was implemented. It was described as "one of the world's most humane" ones (Brochmann and Hagelund 2012, 113) with rather liberal admission criteria for refugees and accesses to permanent residency and citizenship. At the same time, forced migrants began to arrive in larger numbers, 30,000 in the 1980s. A discussion on the structure of the Danish welfare system and the number of arriving refugees and immigrants emerged. This debate resulted in a political attitude that argued so-called "refugees of convenience" would abuse the welfare system (Hedetoft 2006; Brochmann and Hagelund 2012). As a result, the Aliens Act was tightened in 1986 particularly regarding family reunification and benefits aiming to make it less 'attractive' to apply for and obtain asylum or citizenship.

The End of the Cold War as well as conflicts and wars in the Middle East led to the increasing arrival of several new groups throughout the 1990s. Particularly refugees from the former Soviet Union, Bosnians, Iranians, Iraqis, Lebanese and stateless Palestinians characterised arrivals between 1990 and 1999. In 1992, the law regulating family reunification was further tightened, completely removing the automatic right to reunification. The controversial public debates on refugees as "welfare scroungers", who would unfairly take advantage of the Danish welfare system, have been further intensified and heavily politicized throughout the 1990s (Brochmann and Hagelund 2012). The establishment of the Danish People's Party (DPP) in 1995 and its success is a result of immigrant issues dominating the electoral campaigns since then and an atmosphere of deterrence and minimizing 'pullfactors' for immigration (Hedetoft 2006). Denmark's further developments regarding its asylum regime, such as the implementation of the Integration Act of 


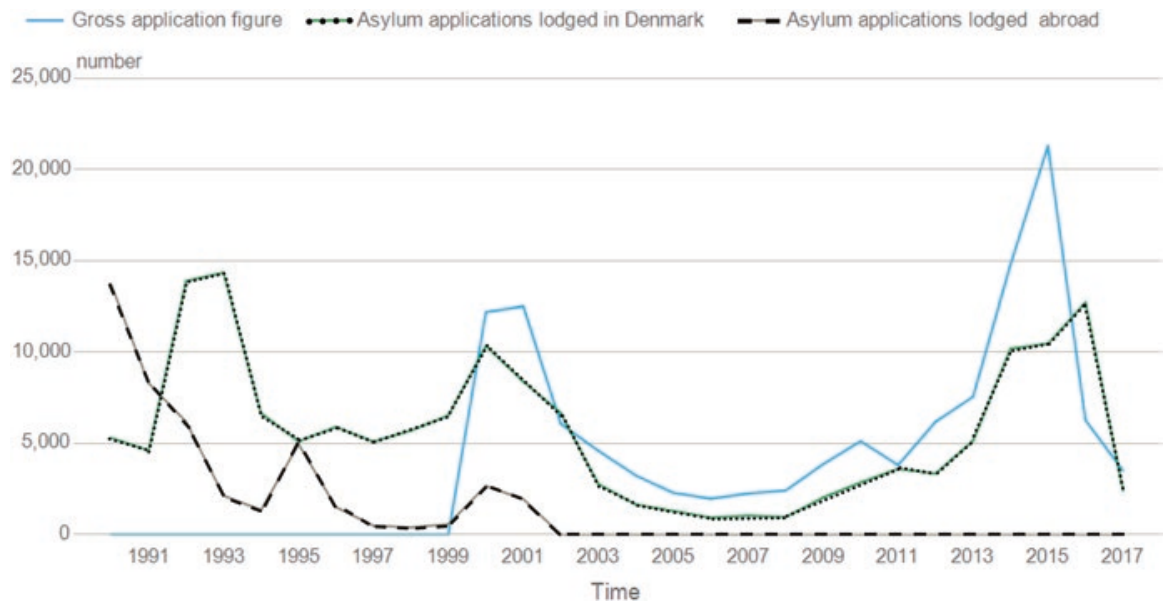

Fig. 3.1 Asylum seekers by type of asylum between 1990 and 2017 (total numbers)

1999, which guaranteed some integration means but which also reduced welfare benefits, are outcomes of these debates (Brochmann and Hagelund 2012).

Understanding the composition of the data on refugee arrivals since 1990 appears to be complex at first glance (see Fig. 3.1). Danish statistics divide the numbers into following variables: application lodged in Denmark by spontaneous refugees ${ }^{1}$, asylum applications that have been lodged abroad and the gross number of applications. ${ }^{2}$ This division is a result of changes in the Danish asylum law throughout the 1990s and 2000s. Until June 2002, the Danish legislation (\$ 7(4) Alien Act) enabled asylum seekers to apply for asylum abroad, where Denmark's diplomatic representations had operated a protected entry procedure (Al-Shahi and Lawless 2005). As seen in figure one, applications lodged abroad had a huge impact in the 1990s. Especially in 1990 (72\%), 1991 (64\%) and 1995 (50\%), more asylum applications have been submitted abroad then on Danish soil.

When only focusing on applications lodged in Denmark, the numbers show that around 8000 applications have been submitted each year with climaxes in 1993 $(14,347)$ and 2000 (10,347). From 2008 on, asylum applications were slowly increasing until 2012, but since 2012 they have been growing heavily mainly due to on-going tense situations in Iran, Afghanistan and the war in Syria. Consequently, the numbers tripled from 3336 in 2012 to 10,192 in 2014 (see Fig. 3.1). Figure one further shows occurrence of gross application numbers since 2000. This is because this value covers all people who have applied for asylum in Denmark, including

\footnotetext{
${ }^{1}$ Danish authorities call persons that apply asylum on the soil of Denmark and that have been travelling independently (without institutional help) spontaneous asylum seekers. Compared to quota refugees, who have been settled to Denmark through the UNHCR's resettlement program, they claim asylum when they arrive at the border of the Danish territory.

${ }^{2}$ Danish official statistics do not include quota refugees of which around 500 arrive every year.
} 
people, who were returned to a safe third country, transferred or re-transferred to another EU Member State under the Dublin Regulation as well as disappearances and withdrawals etc. during the asylum procedure.

As seen in figure one, there is an increasing discrepancy between gross application figures and figures for applications that are being proceeded in Denmark. This is an indication for Denmark's strict accomplishments of the Dublin- and Safe-Third-CountyRegulations throughout the 2015 "refugee crisis", which resulted in lower numbers of registrations and asylum cases that have been processed in Denmark. Compared to other EU member states, particularly Germany and Sweden, asylum applications lodged in Denmark stared dropping by the beginning of 2015 and they remained relatively steady throughout that year. In total, 21,315 applications have been filed in 2015, an increase of $43 \%$ compared to 2014 . The number of cases that are being effectively processed in Denmark remains almost the same though (10,921 in 2014; 10,472 in 2015) and clearly lower than in 1992 and 1993. Since 2016, arrivals started falling significantly. In 2017, around 2500 forced migrants applied for asylum, the lowest number in Denmark for 8 years. Twenty six per cent of asylum applications were successful in 2017, whereas the rate was around 85\% in 2015 and 2016. The main refugee groups since 2014 are Syrians, Iranians, Afghans, Eritreans, Stateless people and Iraqis.

\subsection{The Development of Denmark's Asylum Legislations}

One major characteristic defines the Danish asylum system compared to other EU member states: Denmark abstains from membership in CEAS. It can withdraw EU decisions made about foreigners in Denmark. The following sections analyse the genesis and changes of the legislations in detail. They focus particularly on Denmark's exceptional approaches and on recent law changes.

\subsubsection{Abstaining CEAS and Implemented EU Regulations}

Denmark holds opt-outs from EU policies in the fields of security and defence, citizenship, police and justice, home affairs and the adoption of the Euro. They are set down in the Edinburgh Agreement. The core directives of CEAS, which characterise the EU asylum policy and include Council Directive 2003/9/EC on the reception of asylum seekers, the Council Directive 2004/84/EC on the qualification and status of asylum seekers and the Council Directive 2005/85/EC on the asylum procedure, are not implemented. Triggered by EU's moves in the field of asylum, Denmark, however, has introduced similar laws to its domestic legislations by practicing its right as an international sovereign to enter parallel agreements with other entities (Adler-Nissen 2013, 68). Major agreements are the application of the Schengen 
acquis, the Dublin Regulation and the EURODAC. They allow Denmark to participate in certain means to the EU asylum framework (Tonsberg 2011). In following areas, Denmark has applied different policies:

First, Danish law does not adopt Article 15 of the EU Qualification directive, which enables subsidiary protection in case of a person's fear of death penalty or execution, torture and threat to a civilian's life "by reason of indiscriminate violence in situations of international or internal armed conflict". As a result, many asylum seekers, for example from Afghanistan, Iraq and Somalia, which get often granted subsidiary protection in other EU states, are rejected in Denmark. Compared to the EU directive, Danish asylum law does also not recognise sexual orientation as a social group eligible for refugee status. Second, the Danish asylum policy is characterised by a special definition of refugees: A person must be individually persecuted and prove s/he is personally in a specific danger (Article 19(1)(i)). The Refugee Convention, however, finds it sufficient to belong to a persecuted group or come from a very insecure area. Third, the application for family reunification for refugees with temporary protection is highly restricted: Spouses must be above the age of 24; the spouse in Denmark must finance the move to Denmark, give a financial guarantee of around 7000 Euro and s/he should have not received state benefits for the past 3 years. The waiting period before a refugee can apply for reunification is 3 years. Fourth, regarding the reception, there is an increasing use of detention. This will be outlined in the following sections more specifically.

Denmark's special role is strongly rooted in the fear of losing its national identity in a unified Europe and that the EU would undermine its social-welfare system and standard of living (Brochmann and Hagelund 2012). Because Denmark signed the 1951 Refugee Convention and the European Convention on Human Rights, the significance of Denmark abstaining CEAS is reduced. Nevertheless, Denmark's dealing with family reunification, cuts of benefits and detention practices have caused tensions with the EU and the UN (Dearden 2016).

\subsubsection{Denmark's Reception and Integration Conditions}

There are two core acts that define Denmark's reception and integration conditions: The Aliens Act, initially introduced in 1983, and the Integration Act, established in 1999. Both acts have been repeatedly revised; the Aliens Act alone experienced more than 100 amendments. The revisions have been focussing on reforming the asylum policy and institutional responsibilities, but they also show a clear pattern of restrictive measures, particularly since the early 1990s (Jensen 2012).

The changes to the Aliens Act in the 2000s have been quite fundamental. The right-wing alliance of the Liberal Party Venstre and the Conservative People's Party with support of the right-wing populist DDP created the Ministry for Refugees, Immigrants and Integration of Denmark in 2001. Its objective was to prevent Denmark from becoming a multicultural country, to limit the number of arrivals and the number of people being granted asylum as well as to promote a cultural assimi- 
lation of admitted immigrants (Hedetoft 2006). Assimilation in the Danish context means that the existence of cultures other than the Danish understanding of culture is restricted and seen as problematic (Wren 2001). In 2002, amendments to the Aliens Act involved, among other things, the abolishment of the de facto refugee concept and the possibility to apply for asylum at a Danish mission abroad. Stricter conditions for family reunifications were introduced (L 152). These changes resulted in a significant drop of asylum applications between 2001 and 2008 (see Fig. 3.1).

In 2011, a new government coalition between the Social Democrats, the Danish Social Liberty Party and the Socialist People's Party removed the Immigration Ministry, with a redistribution of duties under the Justice and Social Affairs departments. The Danish Ministry of Justice and its subordinated authority of the Danish Immigration Service are administrable in charge for the reception and integration of forced migrants. Despite promises to improve the conditions for forced immigrants (Asylret 2014), amendments to the Aliens Act included the further expansion of a parallel welfare system, providing significantly lower state support for forced migrants applying for asylum.

The amendments include possibilities to work (Article 14a(1)(ii)) and to live outside of asylum centres (Article 42k. (1)(i)) after staying 6 months in Denmark and living in an asylum accommodation. These require a cooperation contract between the Immigration Office and the asylum seeker, which declares that "the alien cooperates in obtaining information for the assessment of his application for a residence permit (...) and, upon refusal or waiver of the application for a residence permit, cooperates in his departure without undue delay (...)" (42k.(vi)(5)). Signing the contract can engender an immediate departure after the first rejection of the case and thus circumvent the possibility to appeal the decision in front of the Refugee Board. Thus, most asylum seekers decide not to sign the contract.

Upon arrival, asylum seekers are taken to registration at the Sandholm Centre, Denmark's official reception centre, where they are accommodated up to 6 months. Denmark's centre system is characterised by three different types. Sandholm, which houses approximately 600 asylum seekers, a detention centre close to Sandholm run by Danish Prison and Probation Service, and 32 accommodation centres in 2016. The Danish Red Cross operates most accommodations. It manages all humanitarian aspects of the accommodation including Sandholm (Article 42(5) Alien Act). The Danish Ministry of Justice and the Danish Immigration Service decide on the legal regulations, locations of centres and living standards.

The reception as laid down in the Aliens Act serves to exclude asylum seekers from relevant social institutions and integration means (housing, labour market, education, welfare) until the "applicant" proves to be eligible for state protection. Once forced migrants are granted asylum, they are confronted with several assimilationist responsibilities to acquire access to the Danish society. These rights and obligations were established in the Act on Integration in 1999. The Danish Refugee Council (2015) summarizes this logic in an interview as follows:

As long as you are an asylum seeker, we will try to keep you out as hard as we can, you will be placed as far away as we can and you will not learn Danish, you will not be able to get a job. By the minute you get your residence permit, you are forced to integrate as fast as you 
can. [...] You must become a part of the society, which you have been kept away from it for often some years.

The Danish Integration Act was one of the first of its kind in Europe, developed to regulate and control integration. It includes requirements for accessing permanent residency and citizenship. The Integration Act contains a 3-year introduction and integration program, courses on culture and society as well as job related activities during which refugees over age 18 are expected to learn Danish (based on provided courses) (\$21(1)) and to familiarize themselves with Danish history. All refugees and reunified family-members are obliged to follow the programs to be able to access social benefits called "start allowance", which, however, are substantially lower than corresponding benefits.

Fundamental parts of the Integration Act are a compulsory Contract of Integration and a Declaration on Integration and Active Citizenship, which refugees must sign. In these documents, refugees must ensure their loyalty to 'Danish values' (Hedetoft 2006). Refugees and reunified families "are further asked to confirm their willingness to obey Danish law, to respect democratic principles, to learn the Danish language, to acknowledge principles of gender equality, to respect liberty of conscience and freedom of speech, to refrain from carrying out terrorism etc." (Mouritsen and Hovmark Jensen 2014, 11). It describes also "occupational or educational goals and determine the contents of the activities necessary to ensure fulfilment of the goals set out in the contract" $(\$ 19)$. The contract specifies the sanctions applicable according to legislation to the refugee if s/he fails to appear at or rejects one or more of the activities agreed in the individual contract.

The Integration Act changed the distribution and integration conditions and trajectories of refugees. On the one hand, it assigns the main responsibility for integration of refugees to the municipality once a residence status is granted $(\$ 16)$. The municipalities are in charge to ensure that refugees meet the requirements of the act and the contracts. On the other hand, the state "has absolute control over refugee settlement policies" and their housing patterns (Myrberg 2017, 329). The Immigration Service decides where in Denmark the refugee must live without her/ him participating in the decision-making process. This is realized by quota systems, which I explain in the analyses of the Hovedstaden region more precisely.

\subsubsection{The "Refugee Crisis" and Its Consequences}

In 2016, the Ministry for Migration and Integration was re-established under the new right-wing government. It is responsible for all issues related to asylum. In 2015 and 2016, the Danish Parliament adopted several changes, such as L 87 and L 62 , to the Aliens legislation, which aim at conveying a message to make it "less attractive" to seek asylum in Denmark and to protect Denmark's social cohesion and identity (Udlændinge-, Integrations- og Boligministeriet 2016). The amendments have raised "serious concerns of conformity with human rights standards" by 
refugee organisations, the EU and the United Nations (Council of Europe 2016), because they reduce welfare support, enhance detention practices and complicate means such as family reunification and residence permits tremendously. The law includes major shifts in following fields:

1. Qualification and status conditions: The new law reduces the period of asylum as follows; convention status holders: two years (instead of five); individual protection status holders: one year (instead of two); subsidiary protection status holders: one year (instead of five) and temporary subsidiary protection holders: one year (instead of two). ${ }^{3}$ The right to family reunification for refugees with temporary protection (subsidiary forms of protection under Article 7 (3) of the Aliens Act) changes from one to three years. The possibility to obtain legal residence changes from five to six years. Applicants must pass a test for Danish level two (instead of one) and they must provide full-time employment for two and a half years out of the last three years at the time of application compared to three out of five years.

2. Detention: L 62 concerns immigration-related detention introducing circumstances such as massive arrivals for detaining asylum seekers (Aliens Act, article 36, L 62). Article 36 further states that police are entitled to detain an asylum seeker in the context of her/his arrival to Denmark, for the purpose of verifying her/his identity, conduct registration and establish the basis for her/his application. Article 59(1) provides the possibility of imprisonment for up to six months for non-citizens who enter or leave Denmark at a non-designated passport checkpoint or stay in Denmark without the requisite permit. The new laws are related to the introduction of new detention facilities such the Vridsløselille Prison, a former prison now used exclusively for immigration related reasons. Rejected asylum seekers can be detained for up to 18 months without committing crime.

3. Reception conditions and extension of asylum austerity: Various measures that reduce benefits to asylum seekers and at the same time include asylum seekers and refugees in covering the costs related their reception characterise the new Aliens Act. "User charges" have been introduced, which include to pay fees to access application to: family reunification (for subsidiary protection holders, $\approx 940$ Euro), extension of residence permit ( $\approx 242$ Euro), appeal of rejection of applications $(\approx 108$ Euro) (Article 5.7.2). The new law (Article 40 (9)) further allows police to seize asylum seekers' assets to cover the costs of institutional assistance (accommodation, food and health service). It enables officials to force asylum seekers to cede resources such as cash, valuables, including gold and jewellery, exceeding 1340 Euro upon their arrival in Denmark. If the asylum seeker is in possession of adequate funds, the Danish Immigration Service will not provide subsistence allowances and/or state-financed accommodation. Ironically, the amendments abolished the possibility to live outside of centres after six months upon; living in a centre is obligatory. Asylum seekers are thus

${ }^{3}$ For a detailed overview on the changes of periods (and possibilities of extension) of different forms of asylum see UNHCR Regional Representation for Northern Europe (2016). 
forced to pay for their place in a state-financed centre. The changes further focus on increasing the capacity for accommodation and the role of municipalities and private companies in operating centres to reduce costs for accommodation due to competition of a diverse set of operators. Social benefits for arrivals after 2015 are cut down by around 50\%. A single asylum seeker in the phase of the asylum procedure, who is served with canteen services, receives approx. 1.10 Euro per day and approx. 33.20 Euro per month. Asylum seekers with access to selfcatering receive 8.20 Euro per day and approx. 243 Euro per month in total cash allowance (section 7). Section 6.2.2 even lists that, "it is reasonable to foreigners to pay for their stay in detention centres as long as they have the means to do so" (translated into English).

Despite recent changes and falling numbers, Denmark discusses further steps to ultimately stop arrivals. Since 2015, Denmark has published ads in newspapers in countries of the Middle East to promote its strict laws and demotivate migrants. In December 2017, the Danish parliament decided to opt out of the UN refugee resettlement programme, through which Denmark accepted around 500 refugees each year since 1989. In February 2018, the Social Democrats, the Danish parliament's biggest opposition party, pushed forward a discussion on the establishment of Danish-run reception centres in North African countries, which would determine decisions on asylum and protection statuses. This approach includes the abolishment to claim asylum on Danish soil (The Local DK 2018) and ultimately the right to asylum.

\subsection{The Socio-Spatial Exclusion of Forced Migrants in the Hovedstaden Region}

Denmark's Hovedstaden Region covers a great part of northeast Zealand including the greater Copenhagen area and Bornholm island. It is the most densely populated region in Denmark comprising around 1,753,000 inhabitants on $2546.3 \mathrm{sq} . \mathrm{km}$. Copenhagen is the largest city of Hovedstaden; its administrative seat is in Hellerød, a middle-sized town $30 \mathrm{~km}$ north of Copenhagen. Compared to other Danish regions, Hovedstaden has a long tradition in accommodating asylum seekers.

In this section, I explain how Denmark's legislations and policies affect the living conditions and processes of socio-spatial exclusion of forced migrants. First, I elaborate Denmark's agenda to concentrate asylum seekers in remote centres and to prevent newcomers from living in areas with higher percentages of immigrants. Second, I analyse the process of campization and asylum austerity as results of recent law changes. 


\subsubsection{The Danish Policy of Siting Centres and the Territorialisation of Refugees}

Denmark’s Integration Act ( $\$ 8)$ follows the logic to place asylum seekers in remote areas outside of urban settlements and to disperse accepted refugees to municipalities with low immigrant populations to guarantee a "better integration". The instruments for this policy are quota systems of the Immigration Service that regulate the allocation of accepted refugees to regions (Regionskvoter) and municipalities within the regions (Kommunekvoter). The quota is calculated based on the number of residents of a municipality in relation to Denmark's total population, the number of immigrants in a municipality as well as the number of family reunifications in municipalities. Municipalities that already have a high percentage of individuals with foreign origin, with Copenhagen, Arhus and Aalborg leading the way, are socalled "0-Municipalities" meaning that no refugee can move or be distributed to these cities. The explicit intention is to "share the burden of immigration" and create an equal distribution across all municipalities, so that integration can be improved (Danish Immigration Service 2017).

This distribution system has significant effects on the integration trajectories of asylum seekers: first, gives absolute control to the state regarding refugee settlement. Second, it has a long-term effect on the mobility of refugees, who must live for 3 years in the assigned municipality. Third, the municipality is responsible to ensure that refugees participate in the 3-year integration program as well as to sanction refugees if they do not follow the requirements. And fourth, the policy is assimilationist and anti-urban. It argues that the concentration of immigrants in larger cities would circumvent integration. It does not consider the role of ethnic communities and urban ethnic infrastructures as part of integration processes. Instead, it follows the logic to integrate the individual into the Danish society detached from ethnic communities and cultural practices.

This quota also impacts the distribution of asylum centres to less populated areas with low shares of immigrants. It is applied to justify the remote location of centres: Since accepted refugees do not have access to bigger cities, it would not be feasible to open centres in 0-municipalities. In Hovedstaden, all 0-municipalities (Albertslund, Brøndby, Høje-Taastrup, Ishøj and Copenhagen) are in Greater Copenhagen. As a result, there is no asylum centre in or in the neighbouring municipalities and suburbs of Denmark's capital city. The closest centres to Copenhagen are Centre Kongelunden (10 km to the city centre) and Centre Sandholm (30 km to the city centre) (see Fig. 3.2). Neither asylum seekers nor refugees have the legal opportunity to live in bigger cities. In Hovedstaden, centres are predominantly located in former military bases and hospitals in forests $10-50 \mathrm{~km}$ away from larger urban settlements. Particularly the location of centres in Bornholm is striking: Three shelters are located on the remote and sparsely populated isle of 39,756 inhabitants. One ferry connects Bornholm with the Danish mainland taking approx. 5 h. ${ }^{4}$

\footnotetext{
${ }^{4}$ The centres and living conditions of asylum seekers on Bornholm have not been further investi-
} 


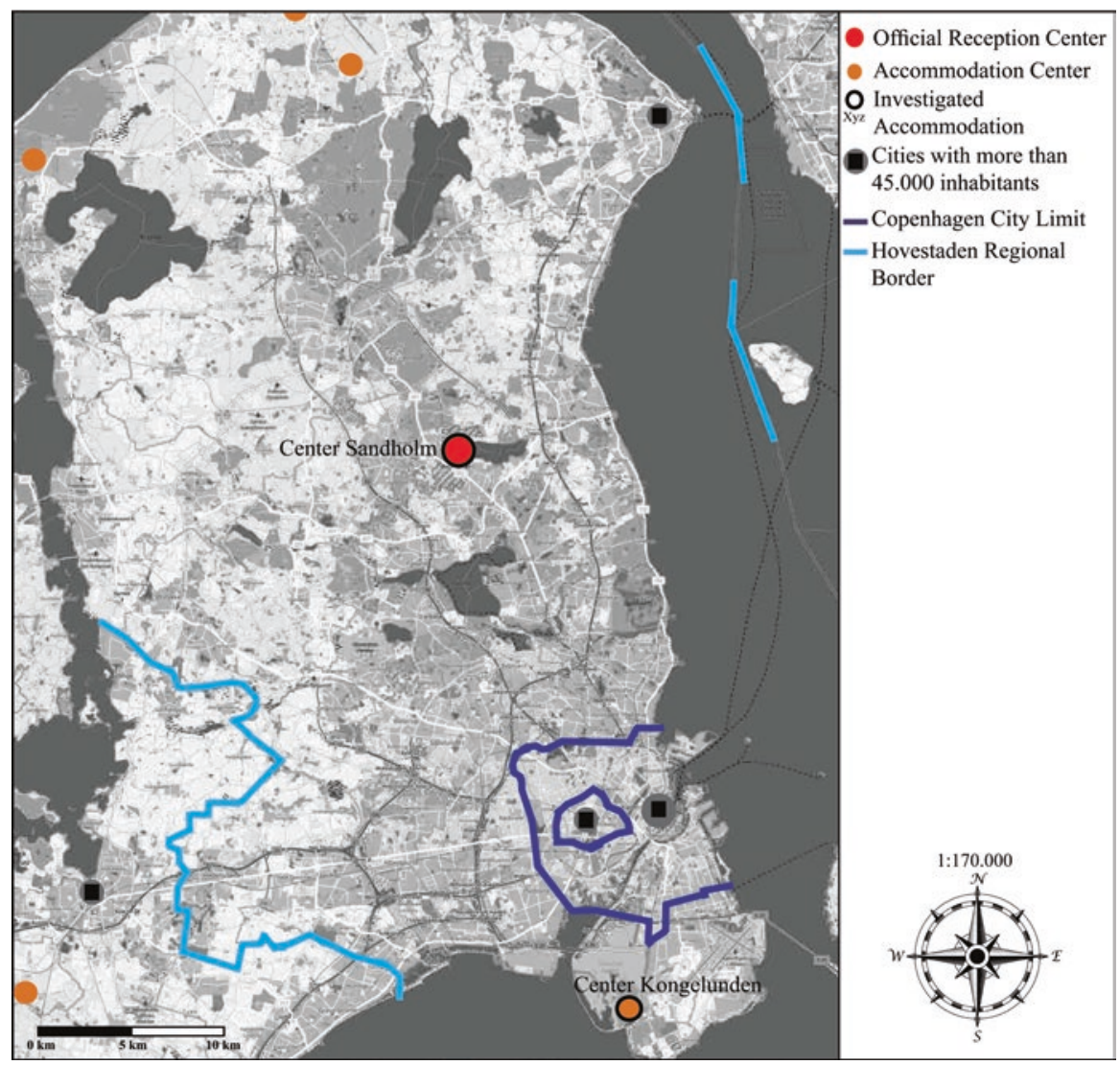

Fig. 3.2 Schematic map of accommodation forms and their distribution in Hovedstaden (without Bornholm) in 2016. (Map modified by including data and information on accommodation, which are based on conducted interviews, own mappings and socio-spatial analyses, as well as on data provided by Røde Kors (2016). Røde Kors Asylcentre. https://www.rodekors.dk/det-goer-vi/ roede-kors-asyl/asylcentre. Accessed 9 December 2017. This map was published in a previous publication: Kreichauf (2018))

There are five accommodations in Hovedstaden's mainland and Centre Avnstrup, which situated close to the region. Sandholm is a central landmark in the Danish system and in Hovedstaden. The old, yellow military barracks were built in 1909 and opened in 1986 as an accommodation site. The centre is located some $30 \mathrm{~km}$ north of Copenhagen. It houses the immigration section of the Danish National Police, the Immigration Service, and Ellebækhus, Denmark's institution for detained asylum seekers operated by the Danish Prison and Probation Service. Sandholm

gated within the presented research material. 
accommodates up to 600 individuals, who are either newly registered, awaiting a decision on their application, or have had their application rejected and are awaiting departure from Denmark.

The Centres Kongelunden, Auderød, Gribskov and Esbonderup are run by the Danish Red Cross. They house 200 to 500 asylum seekers. The Danish Immigration Service (2014) argues in an interview that "smaller units are not very well and expensive to have." 5 The location in rural areas as well as processes of dispersion and concentration characterise the accommodation of forced migrants in Denmark.

\subsubsection{Campization and Asylum Austerity}

In Denmark, the establishment of mass accommodation is strongly connected to the discourse on the abuse of asylum, the 'protection' of the Danish society as well as the introduction of restrictive policies. These conditions unfold in the spatial form of the centre aiming to discourage refugees to migrate to Denmark by strategically reducing the living conditions and accesses to the Danish society. A representative of the Danish Refugee Council (2015) argues that this strategy is the inherent logic of Denmark's reception system:

They do not want to make them feel too comfortable, because they are afraid that more refugees would come. This is very persistent in the society of Denmark. It is a very nationalistic discussion on how to protect the Danish society.

Recent changes in asylum laws and accommodation practices have introduced or enlarged centres, higher capacities and a longer detention time with the purpose of securing the containment and territorialisation of refugees.

Regarding accommodations in the Hovedstaden region, this process of campization is revealed by five major characteristics. First, the isolating location and the socio-spatial structures of the accommodation are defined by the establishment of consolidated and secluded spaces separated from urban settlements. Those camp spaces illustrate a parcel-like organisation of land and buildings, means of centrality within these camp-like settlements, border and surveillance infrastructures, a concentration of the functions reception, accommodation and deportation at one place and own infrastructures within the camps (schools, clinics, canteens, job centres, washhouses). Further, there is a social differentiation and segregation of the residents depending on their status, the legal characteristics as well as characteristics regarding race/ethnicity, gender, age and family status.

Second, control is a central element. There are direct and indirect means of control in centres in Hovedstaden. For example, identity and entry controls of residents and visitors and physical boundaries like fences and walls guarantee direct control.

\footnotetext{
${ }^{5} \mathrm{~A}$ place for one asylum seeker in a centre costs around 750 Euro at average. To accommodate a family of four family members thus costs around 3.000 Euro every month. These high expenses for centre housing circumvent the Immigration Service's statement (Refugees Welcome 2015).
} 
Intrusions in the privacy, the control by the staff of the centres on the actions conducted in the centre and outside of it, the control by other asylum seekers and the development of a specific form of self-control characterise indirect forms. These mechanisms are highly interlinked with the asylum process. They have been established not only to organise and manage asylum seekers, but also to sanction them if necessary.

Third, the accommodation system, but also the asylum regime as such, is established around a state of heteronomy. By heteronomy I mean the condition in which state agencies and officials rule to a large extent forced migrants and their lives. It begins with the distribution after arrival. After initial reception at Sandholm, asylum seekers have no influence on their further distribution to accommodation centres or, once asylum is granted, to municipalities. All interviewed asylum seekers in Hovedstaden had to move multiple times without receiving an explanation. This practice results in feelings of fear, the destruction of social relations among residents and the lack of belonging, as a former resident of Sandholm argues:

They can send you all over the country, if they want to. I lived in many centres here in Denmark. And every time, when you have to leave one, you think that they will deport you. You cannot understand the decision of them sending you to a new place.

The heteronomy opens a set of rules, restrictions and dependencies. It detains asylum seekers from having an autonomous life and being perceived as incapable of conducting their own lives. The principle of allowance, the activation program and the organisation of the centre life has huge impacts on the life and the privacy of asylum seekers.

Fourth, stigmatization and racial markings are a crucial and intentional element of campization in Hovedstaden. The accommodation centre plays a crucial role in the formation of resentments towards 'strangers', because of its architecture and structural organisation, its location as well as its symbolism. Because of the allocation of refugees to a negatively connoted space, they are excluded, but noticed and they become visible - this is the starting point for processes of racialisation and "territorial stigmatisation" (Wacquant 2007). Housing in an accommodation produces attention due to the material and inner structures of the camp space (low standards, concentration of people on a very limited space, intrusion into privacy, dependency on social workers, ban from work). To the outside, the centre conveys an image of its residents who are not in accordance with societal norms. These conditions are highlighted in following excerpt of an interview with a representative of Refugees Welcome (2015):

Especially because often asylum centres are old military barracks, you easily get the impression of centres being concentration camps for people that do not belong and are unwanted in the society. The whole constitution of the centre space like barriers, the entrance control, the fact that people live jammed together on a very small space helps to downgrade asylum seekers in the perception of society and thus they are stigmatised as sub-human beings. [...] The location of the asylum centre helps to establish an image on asylum seekers as being criminal and that they are scary. And of course, this is a political will. 
Sandholm is the most obvious socio-spatial expression of the centre representing a place of stigmatization and intimidation. Not only that it is a former military basis with a history still present in the architecture and in the arrangement of buildings, but also a shooting range of the Danish military surrounds the centre. Gunnery exercise starts every day at 6 a.m. Major sport facilities (the biggest playground, soccer field etc.) are located towards the borders of the centre to the neighbouring detention section. A refugee and member of Asylret remembers: "In Sandholm, in the kindergarden, you can look to the prison for the people that have to leave the country" (Asylret 2014). These conditions further add to the traumatization of asylum seekers.

Finally, Denmark's emerging asylum austerity politics and the mantras of cuts of social benefits and the refugees' contribution to financing the reception system cement campization processes and the position of refugees in society. Since 2003, the government introduced an activation program in the centres overseen and conducted by the Danish Red Cross. The program is mandatory and asylum seekers above the age of 18 must participate otherwise their financial means are cut. It contains daily activities at the centre such as cleaning shared facilities, doing laundry, recycling and bicycle repair (Hobers 2006). These activities are negotiated and distributed by a Job Centre located in the camp. To finance the activation programme, the cash allowances for asylum seekers were lowered, but they regain it by participating at the program (Syppli Kohl 2016). A former employee of the Danish Red Cross (2015) describes the programme in an interview as follows:

\footnotetext{
There is a thing called "Cleaning". Used to control the behaviour, I would say. Because you have to do it, and if you are not doing it, your money will be cut [...]. And then you have activation within the centre, which [...] could be opening and closing the room of the washing machines - completely silly, you don't learn anything. The whole idea is that people [...] get "qualifications" that enables them either to have a good time here or to return. This is the formula in the Red Cross. People are prepared to leave Denmark.
}

The program is related to means and functions of (non-punitive) prison labour consequently aiming to discipline, control and exploit asylum seekers with little paid and manual labour activities. It aims to economise the asylum seekers' maintenance, to save expenses on the reception and it introduces ways to penalise those who do not participate (Syppli Kohl 2016). Consequently, it follows the neoliberal logic of promoting and demanding with asylum seekers being exploited and forced to participate in the preservation of this system.

Denmark has carried asylum austerity measures to extremes. Indeed, cuts in social benefits, integration programs, administrative staff and generally the objective to minimize the expenses for the maintenance of asylum seekers and refugees have some tradition in Danish legislations and political discourses. But Denmark's new approach of appropriation of property and financial means as well as the contribution of asylum seekers' finances and labour power to cover expenses related to their stay is another step towards the disfranchisement and degradation of persons seeking protection. 
The poor financial situation and the spatial isolation in the centres result in asylum seekers trying to find other ways to become a part of the society and to liberate themselves from the exclusionary mechanisms. Due to the cuts of benefits, the long periods asylum seekers are forced to live in the centres, and due to the constitution and location of the centres they find informal ways to conduct their lives (small offences, black market, illegal work with no employment rights, riding trains without tickets etc.). In the end, this situation reinforces the development of the mentioned stigmas on this group.

\subsection{The Role of the Local in Denmark's War on Asylum}

Forced migrants are excluded in extraterritorial and exceptional places, but included in the structures of government, power and national laws and objectives. The accommodation marks the refugees and portrays their position in society. It is an "Urban Non-Class" (Kreichauf 2016, 194), which cannot be described by typical definitions and structures of classes, but which exists parallel to existing social structures of society. There are laws, institutions and spaces exclusively designed for refugees, which structurally, economically, socially and spatially exclude them from established institutions for citizens of a nation state.

What is most apparent when empirically investigating the quintessence of Denmark's reception practices and accommodation structures is their translation into spatial dimensions. During the application process, the asylum system is designed to give control to the state to isolate forced migrants in camp-like accommodation, to provide as little means as possible, and to ultimately deter forced migrants. The state applies the accommodation to separate the 'own' and the '(ethnic) other', citizens and non-citizens (Turner 2016). It represents the material realisations of asylum laws and it is the physical space of administrative and political acts of power. Law changes during and since the "refugee crisis" have intensified these objectives, even though the case of Denmark illustrates a clear path dependency in the establishment of exclusionary reception practices since the 1990s.

Regarding this book's topic and its focus on the local level and local integration conditions, Denmark's reception and settlement approaches are significant and require further studies for the following reasons. First, municipalities have practically no saying regarding the location and development of accommodations and the distribution of accepted refugees. After receiving asylum, the state decides the location and settlement of refugees based on the Regionekvoter and the Kommunekvoter.

Second, only after the dispersal and settlement in a municipality, local policies become relevant, but they are still embedded in powerful state regulations and the assimilationist 3-year-long integration program. Research on the trajectories of accepted refugees during and after this 3-year residential obligation are necessary to give insights into local integration processes, the role of the municipality and their 
impact on the living conditions of refugees. This will also show if refugees in the end stay in allocated regions or if they finally migrate to urban areas.

Third, the hardening of integration policies, the introduction of the quota system and residential obligations for accepted refugees were influenced by Social Democratic majors of Copenhagen and Aarhus in the 1990s (Myrberg 2017). They saw an unfair distribution of costs and problematic concentrations of immigrants, since refugees would migrate to larger cities and settle in ethnic neighbourhoods. The Danish case refutes - or at least diversifies - the assumption in urban and migration studies that big cities would be a hotbed for progressive and proimmigration policies.

Fourth, Denmark's 'geographies of asylum' are consequently rather rural because of the anti-urban and anti-multicultural integration policies. Accommodation centres for asylum seekers and accepted refugees are distributed to rural areas and small towns with low immigrant populations. However, major refugee organizations, initiatives and places of protest are in Copenhagen. The Trampoline House, for example, is a cultural and social project, which aims to "deisolate asylum seekers and include them in the urban society" (Trampoline House 2015). Further analyses should investigate to what extent refugees develop tactics and strategies to participate in urban life and ethnic cultural activities in urban localities.

\section{References}

Adler-Nissen, R. (2013). Justice and home affairs - Denmark as an active differential European. In L. Miles \& A. Wivel (Eds.), Denmark and the European union (pp. 65-79). London/New York: Routledge.

Al-Shahi, A., \& Lawless, R. (2005). Middle East and North African immigrants in Europe. New York: Routledge.

Aumüller, J., Biesenkamp, C., \& Daphi, P. (2015). Die Aufnahme von Flüchtlingen in den Bundesländern und Kommunen. Behördliche Praxis und zivilgesellschaftliches Engagement. Stuttgart: Robert-Bosch-Stiftung GmbH.

Boserup, R. A. (2016). Denmark's Harsh new immigration law will end badly for everyone. Huffington Post. http://www.huffingtonpost.com/rasmus-alenius-boserup/denmark-immigration-law_b_9112148.html. Accessed 11 July 2017.

Breckner, I. (2015). Refugees in German Cities: Local responsibilities and universal access under conditions of protest and inclusive actions in the civil society. Paper presented at the RC21 International Conference on "The Ideal City: between myth and reality. Representations, policies, contradictions and challenges for tomorrow's urban life", Urbino, Italy, 27-29 August 2015.

Brochmann, G., \& Hagelund, A. (2012). Immigration policy and the Scandinavian welfare state 1945-2010. London: Palgrave Macmillan.

Council of Europe. (2016). Denmark: Amendments to the Aliens Act risk violating international legal standards. https://www.coe.int/en/web/commissioner/-/denmark-amendments-to-thealiens-act-risk-violating-international-legal-standards?desktop=false. Accessed 1 Apr 2018.

Danish Immigration Service. (2017). Visiteringskvoter. https://www.nyidanmark.dk/da-dk/ Statistik/visiteringskvoter/kommunekvoter_2017.htm. Accessed 10 July 2017. 
Darling, J. (2009). Becoming bare life: Asylum, hospitality, and the politics of encampment. Environment and Planning. D, Society and Space, 27(4), 649-665.

Darling, J. (2016). Forced migration and the city - Irregularity, informality, and the politics of presence. Progress in Human Geography, 41(2), 178-198.

Dearden, L. (2016). Denmark refugee law: Concern over 'inhumane' family reunification delays that could cause more deaths. The Independent. http://www.independent.co.uk/news/world/ europe/denmark-refugee-law-concern-over-inhumane-family-reunification-delays-that-couldcause-more-deaths-a6836511.html. Accessed 23 Aug 2016.

Diken, B., \& Laustsen, C. B. (2005). The culture of exception. Sociology facing the camp. London/ New York: Routledge.

Dwyer, P., \& Brown, D. (2008). Accommodating 'others'?: Housing dispersed, forced migrants in the UK. Journal of Social Welfare and Family Law, 30(3), 203-218.

Edkins, J. (2000). Sovereign power, zones of Indistinction and the camp. Alternatives: Global, Local, Political, 25(1), 3-25.

EMN European Migration Network. (2014). The organisation of reception facilities for asylum seekers in different member states. http://www.bamf.de/SharedDocs/Anlagen/DE/ Publikationen/EMN/SyntheseberichteEMN-Inform/emnsynthesebericht-aufnahme-unterbringung-asylbewerber.pdf?_blob=publicationFile. Accessed 23 May 2017.

Hedetoft, U. (2006). Denmark: Integrating immigrants into a homogeneous welfare state. Migration information source. Washington, DC: Migration Policy Institute.

Hirschler, S. (2013). Beyond the camp: The biopolitics of asylum seeker housing under the UK. The Modern Law Review, 45(2), 179-197.

Hobers, M. (2006). Report of an exchange programme in Denmark. Report of the Danish Red Cross Asylum Department.

Hyndman, J. (2000). Managing displacement: Refugees and the politics of humanitarianism. Minneapolis: University of Minnesota Press.

Ikizoglu Erensu, A., \& Kasli, Z. (2016). A tale of two cities: Multiple practices of bordering and degrees of 'transit' in and through Turkey. Journal of Refugee Studies, 29(4), 528-548.

Jaffe-Walter, R. (2016). Coercive concern: Nationalism, liberalism, and the schooling of Muslim youth. Stanford: Stanford University Press.

Jensen, J. (2012). Position paper. Copenhagen: Ministry of Interior Denmark.

Jønson, H. V., \& Peterson, K. (2012). Denmark: A national welfare state meets the world. In G. Brochmann \& A. Hagelund (Eds.), Immigration policy and the Scandinavian welfare state 1945-2010 (pp. 97-148). New York: Palgrave Macmillan.

Kingsley, P. (2016). UN backlash against call to scale back Geneva convention on refugees. The Guardian. https://www.theguardian.com/world/2016/jan/06/un-backlash-against-call-to-scaleback-geneva-convention-on-refugees. Accessed 18 Aug 2016.

Kreichauf, R. (2016). Europäische Lagerlandschaften. Zur Unterbringung von Asylsuchenden in Berlin, Kopenhagen und Madrid. In U. Altrock \& R. Kunze (Eds.), Stadterneuerung und Armut. Jahrbuch Stadterneuerung (pp. 171-200). Heidelberg: Springer VS.

Kreichauf, R. (2018). From forced migration to forced arrival: The campization of refugee accommodation in European cities. Comparative Migration Studies, 6(7), 1-22.

Kreichauf, R. (2019). Challenging small towns, again: The arrival, integration and out-migration of repatriates and refugees. Journal of Ethnic and Migration Studies. (under review).

Kublitz, A. (2016). The ongoing catastrophe: Erosion of life in the Danish camps. Journal for Refugee Studies, 29(2), 229-249.

Kusenbach, M. (2003). Street phenomenology. The go-along as ethnographic research tool. Ethnography, 4, 455-485.

Larsen, B. R. (2011). Becoming part of welfare Scandinavia: Integration through the spatial dispersal of newly arrived refugees in Denmark. Journal of Ethnic and Migration Studies, 37(2), $333-350$. 
Lidén, G., \& Nyhlén, J. (2016). Structure and agency in Swedish municipalities' reception of unaccompanied minors. Journal of Refugee Studies, 29(1), 39-59.

Malkki, L. (1995). Refugees and exile: From "refugee studies" to the national order of things. Annual Review of Anthropology, 24, 495-5. (495-523.

Mouritsen, P., \& Hovmark Jensen, C. (2014). Integration policies in Denmark. INTERACT Research Report 2014/06. http://cadmus.eui.eu/bitstream/handle/1814/32020/INTERACT-RR-2014_06. pdf?sequence=1. Accessed 13 Aug 2016.

Myrberg, G. (2017). Local challenges and national concerns: Municipal level responses to national refugee settlement policies in Denmark and Sweden. International Review of Administrative Sciences, 83(2), 322-339.

O'Mahony, L. F., \& Sweeny, J. A. (2010). The exclusion of (failed) asylum seekers from housing and home: Towards an oppositional Discourse. Journal of Law and Society, 37(2), 285-314.

Phillimore, J., \& Goodson, L. (2006). Problem or opportunity? Asylum seekers, refugees, employment and social exclusion in deprived urban areas. Urban Studies, 43(10), 1715-1736.

Ramadan, A. (2013). Spatialising the refugee camp. Transactions of the Institute of British Geographers, 38(1), 65-77.

Redclift, V. (2013). Abjects or agents? Camps, contests and the creation of 'political space'. Citizenship Studies, 17(3-4), 308-321.

Rosenberger, S., \& König, A. (2011). Welcoming the unwelcome: The politics of minimum reception standards for asylum seekers in Austria. Journal of Refugee Studies, 25(4), 537-554.

Salih, R. (2017). Bodies that walk, bodies that talk, bodies that love: Palestinian women refugees, affectivity, and the politics of the ordinary. Antipode, 49, 742-760.

Sanyal, R. (2014). Urbanizing refuge: Interrogating spaces of displacement. International Journal of Urban and Regional Research, 38(2), 558-572.

Simpson, G. (2016). Dispatches: Denmark's deterrence tactics on refugees. https://www.hrw.org/ news/2016/03/03/dispatches-denmarks-deterrence-tactics-refugees. Accessed 11 July 2017.

Spicer, N. (2008). Places of exclusion and inclusion: Asylum-seeker and refugee experiences of Neighbourhoods in the UK. Journal of Ethnic and Migration Studies, 34(3), 491-510.

Statistics Denmark. (2018). Asylum applications and residence permits. Data applied for own graphs with the help of a program provided by Statistics Denmark.

Steen, A. (2016). Deciding refugee settlement in Norwegian cities: Local administration or party politics? Journal of Refugee Studies, 29(4), 464-482.

Syppli Kohl, K. (2016). An asylum system in internal conflict. Translated into English by Michala Bendixen and Luise Valentiner. http://refugees.dk/en/focus/2016/april/an-asylum-system-ininternal-conflict/. Accessed 20 Aug 2016.

Szczepanikova, A. (2013). Between control and assistance: The problem of European accommodation centres for asylum seekers. International Migration, 5(4), 130-143.

The Local DK. (2018). Danish social democrats criticised for plan to 'send asylum seekers to Africa'. https://www.thelocal.dk/20180205/danish-social-democrats-criticised-for-plan-tosend-asylum-seekers-to-africa. Accessed 2 Apr 2018.

Tonsberg, M. (2011). Det Danske retsforbehold efter Lissabon-traktaten. In T. NyAgenda (Ed.), EU's Retspolitik Og Det Danske Forbehold (pp. 34-47). Kbh: Tænketanken NyAgenda.

Turner, S. (2016). What is a refugee camp? Explorations of the limits and effects of the camp. Journal of Refugee Studies, 29(2), 139-148.

Udlændinge-, Integrations- og Boligministeriet. (2016). Information about the Danish border control. http://uibm.dk/nyheder/2016-01/information-about-the-danish-border-control. Accessed 20 Aug 2016.

UNHCR Regional Representation for Northern Europe. (2016). UNHCR Observations on the proposed amendments to the Danish Aliens legislation, L 87. http://www.unhcr-northerneurope. org/fileadmin/user_upload/Documents/PDF/Denmark/UNHCR_Comments_on_Danish_law_ proposal_L87_January_2016.pdf. Accessed 12 July 2016. 
Wacquant, L. (2007). Territorial stigmatization in the age of advanced marginality. Thesis Eleven, 91, 66-77.

Witteborn, S. (2011). Constructing the forced migrant and the politics of space and place-making. Journal of Communication, 61(6), 1142-1160.

Wren, K. (2001). Cultural racism: Something rotten in the state of Denmark? Social \& Cultural Geography, 2(2), 141-162.

Wren, K. (2003). Refugee dispersal in Denmark: From macro- to micro-scale analysis. International Journal of Population Geography, 9, 57-75.

\section{Interviews}

Asylum Seekers and refugees. (2015). Various personal interviews with asylum seekers on living conditions and centre housing, 18.01.2014-30.04.2016, Hovedstaden Region.

Asylret. (2014). Personal interview with a representative on the reception and living conditions of asylum seekers in Greater Copenhagen, 27.04.2014, Copenhagen.

Danish Immigration Service. (2014). Personal interview with a representative on Danish asylum legislations and the reception conditions and practices, 29.04.2014, Copenhagen.

Danish Red Cross. (2015). Personal interview with a former employee on the role of the Danish Red Cross in Denmark's asylum system, 21.01.2014, Frederiksberg.

Danish Refugee Council. (2015). Personal interview with a representative on Danish asylum legislations and the consequences of centre housing, 28.01.2014, Copenhagen.

Refugees Welcome. (2015). Telephone interview with a representative on housing practices and the Danish asylum policy, 28.01.2014.

Trampoline House. (2015). Personal interview with two representatives on the objectives of the Trampoline House and the conditions of asylum seekers and refugees in the Hovedstaden region, 28.04.2014, Copenhagen.

\section{Legal Documents}

Consolidation of the Act on Integration of Aliens in Denmark, 05.09.2005, Lov. nr. 839. Retrieved from https://www.nyidanmark.dk/NR/rdonlyres/105C4108-2914-4BCB-B5CE5023B5EF62F7/0/act_on_integration_2005.pdf.

Consolidation of the Aliens Act, 25.06.2013, Lov. Nr. 863. Retrieved from https://www.nyidanmark.dk/NR/rdonlyres/2A42ECC8-1CF5-4A8A-89AC-8D3D75EF3E17/0/aliens_consolidation_act_863_250613.pdf

Council directive 2003/9/EC Laying down minimum standards for the reception of asylum seekers, 27.1.2003, OJ L. 31/18-31/25. Retrieved from http://eur-lex.europa.eu/legal-content/EN/ ALL/?uri=celex\%3A32003L0009

Directive 2013/33/EU of the European Parliament and Council Laying down standards for the reception of applicants for international protection, 29.6.2013, OJ L. 180/96-105/32. Retrieved from http://eur-lex.europa.eu/legal-content/EN/TXT/?uri=celex\%3A32013L0033

Executive Order on Aliens' Access to Denmark (Aliens Order), 24.06.2008, Lov. nr. 635. Retrieved from https://www.nyidanmark.dk/NR/rdonlyres/80A97DB0-B657-4B6D-8734D17BD6AE74C0/0/aliens_order.pdf 
L62 Forslag til lov om ændring af udlændingeloven [L62 Amendment to the Aliens Act], 20.11.2015, Lov nr. 1273. Retrieved from http://www.ft.dk/samling/20151/lovforslag/L62/ index.htm

L87 Forslag til Lov om ændring af udlændingeloven L87 [Amendment to the Aliens Act L87], 12.12.2015, Lov nr. 102. Retrieved from http://www.ft.dk/samling/20151/lovforslag/L87/ index.htm

Open Access This chapter is licensed under the terms of the Creative Commons Attribution 4.0 International License (http://creativecommons.org/licenses/by/4.0/), which permits use, sharing, adaptation, distribution and reproduction in any medium or format, as long as you give appropriate credit to the original author(s) and the source, provide a link to the Creative Commons license and indicate if changes were made.

The images or other third party material in this chapter are included in the chapter's Creative Commons license, unless indicated otherwise in a credit line to the material. If material is not included in the chapter's Creative Commons license and your intended use is not permitted by statutory regulation or exceeds the permitted use, you will need to obtain permission directly from the copyright holder. 